\title{
Effect of Some Weaning Foods on Weanling Albino Rats
}

\author{
Umaru Hauwa Aduwamai ${ }^{1 *}$ and Mahmud Bilkisu Abubakar ${ }^{2}$ \\ ${ }^{1}$ Department of Biochemistry, School of Life Sciences Modibbo Adama University of Technology Yola, Nigeria \\ ${ }^{2}$ Department of Biochemistry, Faculty of Science, Adamawa State University Mubi, Nigeria
}

*Corresponding author: Umaru Hauwa Aduwamai, Department of Biochemistry, School of Life Sciences Modibbo Adama

University of Technology Yola, Nigeria

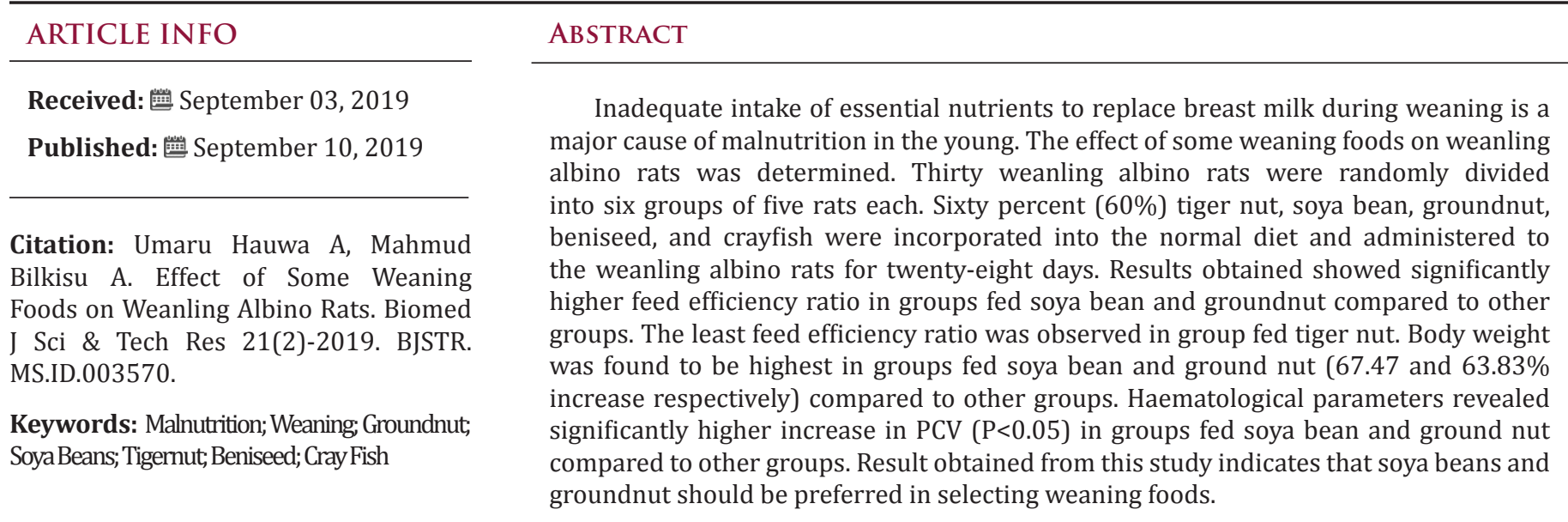

\section{Introduction}

Malnutrition among children is a major public health concern in the developing countries. It affects all aspects of children's life, its effects are not limited to physical health but extend to mental, social, and spiritual well-being [1]. The world health organization estimates that malnutrition accounts for 54 percent of child mortality worldwide [2], while for children under the age of five years, childhood underweight accounts for $35.0 \%$ of all deaths worldwide [3].

Deficiency in energy balance and protein are characteristics of malnutrition, which may impair the proper functioning of various physiological processes [4]. Malnutrition can be caused by several factors such as, inadequate food intake, infections, psychosocial deprivation, and insanitary environment as well as lack of hygiene, social inequality, and possibly some genetic contribution. Reports from different studies report that children who live in households lacking access to sufficient clean healthy food are more likely to be predisposed to

poor nutrition and health related problems than children from food secure households [5]. Malnutrition increases the risk of infection and infectious disease, and moderate malnutrition weakens every part of the immune system [6]. It is a major risk factor in the onset of active tuberculosis [7].

Weaning is a major cause of malnutrition in the world. Weaning is influenced by socioeconomic status, cultural and religious beliefs and practices [8]. Adequate early nutrition is the most essential element in assuring adequate growth and appropriate cognitive and functional development of the infant. Severe protein energy malnutrition results in the clinical syndromes of marasmus, kwashiorkor or marasmic-kwashiorkor. Malnutrition arises due to poverty, ignorance, dietary practices, and agricultural productivity [9]. The aim of this study therefore is to determine the effect of some weaning foods on weanling albino rats with a view to finding the best weaning food. 


\section{Materials and Methods}

\section{Collection and Preparation of Samples}

Glycine max, Arachis hypogaea, Cyperus esculentus, Sesamum indicum L. and Procambarus clarkii were obtained from Mubi market, samples were washed, air dried and ground to powder.

\section{Experimental Animals}

Thirty weanling male albino rats (aged 3 weaks) were obtained from National veterinary research institute Jos. The rats were housed under standard laboratory conditions.

\section{Methods}

Feed Efficiency Ratio (FER): Feed efficiency ratio was calculated using the following formula:
Feed efficiency ratio $($ FER $)=\frac{\text { Gain in body weight }(g)}{\text { Food intake }(g)}$

\section{Body Weight Determination}

Rats were weighed on weekly bases to ascertain weight gain or weight loss for a period of four weeks.

\section{Experimental Design}

Thirty weanling albino rats were randomly divided into 6 groups of five rats each. Group 1 served as normal control, Group 2 served as tiger nut group, Group 3 served as soya beans group, Group 4 served as groundnuts group, Group 5 served as beniseed group, and Group 6 serves as crayfish group. About $60 \%$ of the experimental diet (tiger nut, soyabeans, groundnuts, beniseed, and crayfish) was added to $40 \%$ of the laboratory diet and fed to the animals for 4 weeks as shown in the Table 1.

Table 1: Experimental Design, the rats were sacrificed using chloroform vapor as an anesthesia and blood samples were collected by cardiac puncture into sample bottles.

\begin{tabular}{|c|c|c|}
\hline Group & Description & Treatment \\
\hline I & Diet 1 & Normal feed (100\%) \\
\hline II & Diet 2 & Normal feed (40\%) + Tiger nut (60\%) \\
\hline III & Diet 3 & Normal feed (40\%) + soya bean (60\%) \\
\hline IV & Diet 4 & Normal feed(40\%)+Ground nut (60\%) \\
\hline V & Diet 5 & Normal feed (40\%) + Beniseed (60\%) \\
\hline Vl & Diet 6 & Normal feed (40\%) + cray fish (60\%) \\
\hline
\end{tabular}

\section{Haematological Parameters}

Haematological parameters were determined using automated analyzer. The Parameters include: PCV (Parked cells volume on weekly basis), Red blood cell count, Haemoglobin, Haematocrit, Mean Cell Volume (MCV), Mean Cell Haemoglobulin (MCH), Mean Cell Haemoglobulin Concentration (MCHC), Red Cell Distribution Width (RDW), White Blood Cell Count (WBC), Differential White Cell, Neutrophils Lymphocytes, Monocytes, Eosinophils, Basophils and Platelet count.

Table 2: Feed Efficiency Ratio of Rats.

\section{Results}

Table 2

The feed efficiency ratio of rats fed with different supplement diets for four weeks is as presented in Table 2. The highest percentage of feed efficiency ratio $(82.14 \%)$ was obtained in group fed with soya bean supplement diet, followed by group fed with groundnut (72.16\%). Group fed with tiger nut had the least feed efficiency ratio $(50.35 \%)$.

\begin{tabular}{|c|c|c|c|c|c|}
\hline Groups & WEEK 1 & WEEK 2 & WEEK 3 & WEEK 4 & $\begin{array}{c}\text { \% Increase in feed } \\
\text { efficiency ratio }\end{array}$ \\
\hline 1 (Normal Control) & $8.22 \pm 2.03^{\mathrm{a}, \mathrm{d}}$ & $15.00 \pm 3.05^{\mathrm{a}, \mathrm{c}}$ & $18.31 \pm 3.40^{\mathrm{a}}$ & $23.14 \pm 2.26^{\mathrm{a}, \mathrm{c}}$ & 64.48 \\
\hline 2 (Tiger nut) & $7.80 \pm 1.53^{\mathrm{a}, \mathrm{d}}$ & $9.48 \pm 2.00^{\mathrm{a}, \mathrm{d}}$ & $13.97 \pm 1.01^{\mathrm{b}}$ & $15.71 \pm 1.73^{\mathrm{c}}$ & $50.35^{\mathrm{b}}$ \\
\hline 3 (Soya bean) & $3.71 \pm 0.98^{\mathrm{b}, \mathrm{d}}$ & $5.37 \pm 1.31^{\mathrm{bc}}$ & $10.77 \pm 2.07^{\mathrm{b}}$ & $20.67 \pm 2.11^{\mathrm{c}}$ & $82.04^{\mathrm{a}}$ \\
\hline 4 (G/nut) & $5.47 \pm 1.42^{\mathrm{b}, \mathrm{d}}$ & $9.22 \pm 1.72^{\mathrm{a}, \mathrm{d}}$ & $14.15 \pm 1.14$ & $19.65 \pm 3.90^{\mathrm{c}}$ & 72.16 \\
\hline 5 (Beniseed) & $4.22 \pm 0.65^{\mathrm{b}, \mathrm{d}}$ & $6.71 \pm 1.19^{\mathrm{b}, \mathrm{d}}$ & $10.94 \pm 2.41^{\mathrm{b}}$ & $14.65 \pm 2.34^{\mathrm{bc}}$ & 71.19 \\
\hline 6 (Crayfish) & $5.08 \pm 1.50^{\mathrm{b}, \mathrm{d}}$ & $8.92 \pm 2.26^{\mathrm{a}}$ & $11.28 \pm 1.55^{\mathrm{b}}$ & $13.05 \pm 2.54^{\mathrm{bc}}$ & 61.07 \\
\hline
\end{tabular}

Note: Values are Mean \pm SEM for 5 determinations

$\mathrm{a}=$ significantly higher $(\mathrm{p}<0.05)$ compared to other groups

$\mathrm{b}=$ significantly lower $(\mathrm{p}<0.05)$ compared to other groups

$c=$ significantly higher $(\mathrm{p}<0.05)$ compared $t$ other weeks

$\mathrm{d}=$ significantly lower $(\mathrm{p}<0.05)$ compared to other weeks 


\section{Table 3}

Results of this table revealed a significant increase in body

Table 3: Body Weight of Rats in Grams (g). weight (67.47\%) of group three rats (Soya bean), followed by group fed with groundnut (63.83\%) Tiger nut group had the least weight gain $(41.90 \%)$ (Table 3$)$.

\begin{tabular}{|c|c|c|c|c|c|}
\hline Groups & WEEK 1 & WEEK 2 & WEEK 3 & WEEK 4 & \% Increase in weight \\
\hline 1 (Normal Control) & $76.60 \pm 8.01^{\mathrm{a}, \mathrm{d}}$ & $97.00 \pm 9.92^{\mathrm{a}}$ & $114.00 \pm 11.42^{\mathrm{a}}$ & $155 \pm 15.92^{\mathrm{a}, \mathrm{c}}$ & 50.58 \\
\hline 2 (Tiger nut) & $61.00 \pm 3.67^{\mathrm{d}}$ & $67.00 \pm 4.63^{\mathrm{b}}$ & $73.20 \pm 6.76$ & $105.00 \pm 5.11^{\mathrm{c}}$ & $41.90 \mathrm{~b}$ \\
\hline 3 (Soya bean) & $42.00 \pm 2.34^{\mathrm{b}, \mathrm{d}}$ & $79.00 \pm 4.63^{\mathrm{a}}$ & $91.60 \pm 8.08^{\mathrm{a}}$ & $109.00 \pm 11.51^{\mathrm{c}}$ & $67.47^{\mathrm{a}}$ \\
\hline 4 (G/nut) & $51.20 \pm 2.58^{\mathrm{d}}$ & $81.00 \pm 6.16^{\mathrm{a}}$ & $101.00 \pm 7.1^{\mathrm{a}}$ & $141.00 \pm 14.9^{\mathrm{c}}$ & $63.83^{\mathrm{a}}$ \\
\hline 5 (B/seed) & $51.20 \pm 2.58^{\mathrm{d}}$ & $65.80 \pm 3.89^{\mathrm{b}}$ & $85.40 \pm 6.18$ & $109.00 \pm 13.22^{\mathrm{c}}$ & 53.03 \\
\hline 6 (Crayfish) & $46.40 \pm 2.30^{\mathrm{b}, \mathrm{d}}$ & $61.20 \pm 4.14^{\mathrm{b}}$ & $74.00 \pm 12.30^{\mathrm{b}}$ & $98.40 \pm 17.38^{\mathrm{b}}$ & 52.85 \\
\hline
\end{tabular}

Note: Values are Mean \pm SEM for 5 determinations

$\mathrm{a}=$ significantly higher $(\mathrm{p}<0.05)$ compared to other groups

$\mathrm{b}=$ significantly lower $(\mathrm{p}<0.05)$ compared to other groups

$c=$ significantly higher $(\mathrm{p}<0.05)$ compared to other weeks

$\mathrm{d}=$ significantly lower $(\mathrm{p}<0.05)$ compared to other weeks

\section{Table 4}

The Result of the packed Cell Volume (PCV) is as shown in Table 4. Results obtained showed significantly higher increase in PCV

Table 4: PCV of Experimental Rats in Percentage (\%).

\begin{tabular}{|c|c|c|c|c|c|}
\hline GROUPS & WEEK 1 & WEEK 2 & WEEK 3 & WEEK 4 & \% Increase in PCV \\
\hline 1 (Normal Control) & $44.16 \pm 1.40^{\mathrm{b}, \mathrm{d}}$ & $46.33 \pm 2.51^{\mathrm{a}}$ & $48.58 \pm 7.07$ & $50.91 \pm 2.08^{\mathrm{c}}$ & 13.26 \\
\hline 2 (Tiger nut) & $49.83 \pm 2.11^{\mathrm{ad}}$ & $51.00 \pm 3.46^{\mathrm{a}}$ & $53.30 \pm 2.12^{\mathrm{a}}$ & $56.00 \pm 1.73^{\mathrm{c}}$ & $11.02^{\mathrm{b}}$ \\
\hline 3 (Soya bean) & $46.60 \pm 5.78^{\mathrm{d}}$ & $48.92 \pm 1.50^{\mathrm{a}}$ & $52.00 \pm 3.46^{\mathrm{a}}$ & $57.00 \pm 1.84^{\mathrm{c}}$ & $18.25^{\mathrm{a}}$ \\
\hline 4 (Groundnut) & $44.49 \pm 1.44^{\mathrm{b}, \mathrm{d}}$ & $46.66 \pm 5.77^{\mathrm{a}}$ & $48.93 \pm 1.41$ & $54.00 \pm 0.57^{\mathrm{c}}$ & $17.62^{\mathrm{a}}$ \\
\hline 5 (Beniseed) & $42.97 \pm 1.18^{\mathrm{b}}$ & $44.66 \pm 3.05^{\mathrm{a}}$ & $48.93 \pm 9.89$ & $51.03 \pm 1.15^{\mathrm{c}}$ & 16.73 \\
\hline 6 (Crayfish) & $43.33 \pm 2.01^{\mathrm{b}, \mathrm{d}}$ & $45.33 \pm 3.05^{\mathrm{b}}$ & $47.50 \pm 3.53$ & $49.78 \pm 1.73^{\mathrm{c}}$ & 13 \\
\hline
\end{tabular}

Note: Values are Mean \pm SEM for 5 determinations

$\mathrm{a}=$ significantly higher $(\mathrm{p}<0.05)$ compared to other groups

$\mathrm{b}=$ significantly lower $(\mathrm{p}<0.05)$ compared to other groups

$c=$ significantly higher $(\mathrm{p}<0.05)$ compared to other weeks

$\mathrm{d}=$ significantly lower $(\mathrm{p}<0.05)$ compared to other weeks

\section{Table 5}

The hematological parameters of rats fed with normal feed, tiger nut, soya bean, groundnut, beniseed and crayfish supplemented feeds is presented in Table 5. Hemoglobin, PCV, platelet, RBC, MCH, MCHC and MCV were studied. Hemoglobin levels were relatively higher in group three $(18.66 \pm 1.02)$ fed with soya bean supplement diet and group four $(18.67 \pm 0.74)$ fed with groundnut supplement diet when compared with the control $(16.97 \pm 0.84)$. Tiger nut levels in soya bean group (18.25\%) and groundnut group (17.62\%) compared to other groups. Tiger nut group had the least PCV result $(11.02 \%)$.

Table 5: Haemotological Parameters of Rat Fed with Different Weaning Foods.

\begin{tabular}{|c|c|c|c|c|c|c|c|c|c|c|c|c|c|}
\hline Groups & $\mathrm{Hb}$ & PCV & WBC & RBC & MCH & MCHC & MCV & Platelets & Neutrophils & Eosinophil & Lymphocytes & Monocytes & Basophils \\
\hline 1 (Control) & $\begin{array}{c}16.97 \pm \\
0.86^{\mathrm{b}}\end{array}$ & $\begin{array}{c}50.91 \pm \\
2.08^{\mathrm{b}}\end{array}$ & $\begin{array}{c}5.43 \pm \\
0.55^{\mathrm{a}}\end{array}$ & $\begin{array}{c}5.70 \pm \\
0.17\end{array}$ & $\begin{array}{c}17.00 \pm \\
1.67^{\mathrm{b}}\end{array}$ & $\begin{array}{c}33.40 \pm \\
1.57\end{array}$ & $\begin{array}{c}51.80 \pm \\
1.60^{\mathrm{b}}\end{array}$ & $\begin{array}{l}1.71 \pm \\
0.02^{b}\end{array}$ & $50.66 \pm 3.78^{\mathrm{a}}$ & $1.66 \pm 0.02^{\mathrm{b}}$ & $44.33 \pm 1.52$ & $0.66 \pm 0.01$ & $0.33 \pm 0.01$ \\
\hline $\begin{array}{l}2 \text { (Tiger } \\
\text { nut) }\end{array}$ & $\begin{array}{c}15.54 \pm \\
1.43 b\end{array}$ & $\begin{array}{c}56.63 \pm \\
0.57^{\mathrm{a}}\end{array}$ & $\begin{array}{c}5.03 \pm \\
0.05\end{array}$ & $\begin{array}{l}5.16 \pm \\
0.00^{b}\end{array}$ & $\begin{array}{c}18.80 \pm \\
0.00^{\mathrm{b}}\end{array}$ & $\begin{array}{c}35.33 \pm \\
1.53^{\mathrm{a}}\end{array}$ & $\begin{array}{c}51.93 \pm \\
2.68^{b}\end{array}$ & $\begin{array}{c}1.78 \pm \\
0.04\end{array}$ & $49.33 \pm 1.15 b$ & $2.66 \pm 0.05$ & $44.66 \pm 0.57$ & $1.66 \pm 0.02 \mathrm{~b}$ & $0.33 \pm 0.01$ \\
\hline
\end{tabular}




\begin{tabular}{|c|c|c|c|c|c|c|c|c|c|c|c|c|c|}
\hline $\begin{array}{l}3 \text { (Soya } \\
\text { bean) }\end{array}$ & $\begin{array}{c}18.66 \pm \\
1.02 \mathrm{a}\end{array}$ & $\begin{array}{c}57.00 \pm \\
1.84^{\mathrm{a}}\end{array}$ & $\begin{array}{l}4.63 \pm \\
0.46^{b}\end{array}$ & $\begin{array}{c}5.90 \pm \\
0.10^{\mathrm{a}}\end{array}$ & $\begin{array}{c}21.70 \pm \\
1.13\end{array}$ & $\begin{array}{c}32.60 \pm \\
1.21\end{array}$ & $\begin{array}{c}65.53 \pm \\
1.10\end{array}$ & $\begin{array}{l}1.80 \pm \\
0.01^{\mathrm{a}}\end{array}$ & $54.00 \pm 3.60^{a}$ & $2.33 \pm 0.57$ & $43.33 \pm 4.16$ & $0.02 \pm 0.00^{\mathrm{b}}$ & $\begin{array}{l}0.00 \pm \\
0.00^{\mathrm{b}}\end{array}$ \\
\hline $\begin{array}{c}4 \text { (Grounb } \\
\text { nut) }\end{array}$ & $\begin{array}{c}18.67 \pm \\
0.74^{\mathrm{a}}\end{array}$ & $\begin{array}{c}54.00 \pm \\
0.57^{\mathrm{a}}\end{array}$ & $\begin{array}{c}5.13 \pm \\
0.41\end{array}$ & $\begin{array}{l}5.83 \pm \\
0.41^{\mathrm{a}}\end{array}$ & $\begin{array}{c}19.53 \pm \\
1.33\end{array}$ & $\begin{array}{c}32.86 \pm \\
0.92\end{array}$ & $\begin{array}{c}59.60 \pm \\
5.10\end{array}$ & $\begin{array}{l}1.83 \pm \\
0.01^{\mathrm{a}}\end{array}$ & $58.66 \pm 1.52^{\mathrm{a}}$ & $2.00 \pm 0.00$ & $37.33 \pm 3.21^{\mathrm{b}}$ & $1.00 \pm 0.00^{\mathrm{b}}$ & $\begin{array}{l}0.00 \pm \\
0.00^{\mathrm{b}}\end{array}$ \\
\hline $\begin{array}{c}5 \\
\text { (Beniseeb) }\end{array}$ & $\begin{array}{c}17.01 \pm \\
1.00^{\mathrm{a}}\end{array}$ & $\begin{array}{c}51.03 \pm \\
1.15^{\mathrm{b}}\end{array}$ & $\begin{array}{c}5.00 \pm \\
0.10\end{array}$ & $\begin{array}{l}4.50 \pm \\
0.60^{\mathrm{b}}\end{array}$ & $\begin{array}{c}24.33 \pm \\
4.36^{\mathrm{a}}\end{array}$ & $\begin{array}{c}33.06 \pm \\
0.60\end{array}$ & $\begin{array}{l}75.26 \pm \\
14.33^{\mathrm{a}}\end{array}$ & $\begin{array}{c}1.77 \pm \\
0.02\end{array}$ & $48.66 \pm 0.57^{b}$ & $1.33 \pm 0.57^{\mathrm{b}}$ & $47.66 \pm 0.57^{\mathrm{a}}$ & $1.00 \pm 0.00^{\mathrm{b}}$ & $\begin{array}{l}1.00 \pm \\
0.00^{\mathrm{a}}\end{array}$ \\
\hline $\begin{array}{c}6 \\
\text { (Arayfish) }\end{array}$ & $\begin{array}{c}16.50 \pm \\
0.46^{\mathrm{b}}\end{array}$ & $\begin{array}{c}49.78 \pm \\
1.73^{b}\end{array}$ & $\begin{array}{l}5.23 \pm \\
0.11^{\mathrm{a}}\end{array}$ & $\begin{array}{l}4.03 \pm \\
0.05^{b}\end{array}$ & $\begin{array}{c}25.86 \pm \\
1.85^{\mathrm{a}}\end{array}$ & $\begin{array}{c}33.40 \pm \\
0.79\end{array}$ & $\begin{array}{c}77.13 \pm \\
4.81^{\mathrm{a}}\end{array}$ & $\begin{array}{c}1.79 \pm \\
0.01\end{array}$ & $55.33 \pm 3.05$ & $3.33 \pm 0.57^{\mathrm{a}}$ & $39.00 \pm 5.56$ & $2.66 \pm 0.20^{\mathrm{a}}$ & $\begin{array}{l}1.00 \pm \\
0.00^{\mathrm{a}}\end{array}$ \\
\hline
\end{tabular}

Note: Values are Mean \pm SEM for 5 determinations

$\mathrm{a}=$ significantly higher, compared to other groups

$\mathrm{b}=$ significantly lower, compared to other groups

\section{Discussion}

The high percentage increase in feed efficiency ratio observed in Table 2 for group fed with soya bean supplement diets could be as a result of the high protein content (39.44 g) of soya bean that is required for growth and development by the weanling rats. Soya bean also contains high amount of folic acid (204.16 g) that is required for brain development in weanling children. Increase in body weight observed in group fed groundnut could be as a result of all the essential amino acid content in the diet. Peanuts contain all the essential amino acids necessary for normal body growth and metabolism [10]. From Table 3 above, the gain in weight of rats fed with soya bean and groundnuts supplement diets was significantly higher than the control and other groups fed with different supplement diets. The study reveals a significant increase in body mass of the rats studied. increase in body weights is greatly associated with feed intake and constituent of feed consumed. This increase in body weight is greater with soya bean and groundnuts supplement diets than with the standard feed. This could result from the composition of diets, particularly its high proteins, (required to complement that of breast milk), carbohydrates and fats contents which ensures an adequate intake favorable to the growth of the rats [11]. Soya bean and groundnuts are commonly mixed with other cereals for animal feeds and is the main source of energy for the diet because of its high levels of starch and fatty acids [12]. Globally, soya beans and groundnuts are among the largest sources of dietary protein. This study agrees with the findings of Daniels et al. [13] who stated that among plant proteins consumed, those from soya beans and groundnuts are considered to have a high nutritional value. Decrease in groups fed tiger nut may be due to the fiber content of tiger nut which interferes with iron absorption. The high fiber content of tiger nut may have a good effect on digestion in adults but not in infants [14].

The low body weights of rats fed tiger nuts may also be due to protease inhibitors which affects protein digestibility. Protease inhibitors are globular proteins that bind irreversibly to protease enzymes, thereby inhibiting their proteolytic activities in the digestive tract of both humans and animals. The presence of protease inhibitors in foods decrease protein digestibility, pancreatic hypertrophy, growth inhibition and increase in demand for sulphur containing amino acids [15]. The packed cell volume showed significant increase across all groups. The increase observed was highest in for groups fed with soya bean and groundnut (56.00 \pm 1.73 and $57.00 \pm 1.84$ ) after 4 weeks respectively when compared with the control. Increase in hematological parameters in the animals in this study could be explained by the presence of the various nutritive components contained in the diets. The increase in hematological parameters in some experimental and control groups could be associated with constituent of diets particularly soya bean and groundnut fed diets. Iron is an important co-factor for cytochrome oxidase enzymes at cellular level metabolisms and required for Red Blood Cell (RBC's) productions [16]. Magnesium plays a structural role in bone, cell membranes, and chromosomes [17].

From Table 5 above, the soya bean and groundnut fed group showed significant increase in most of the haematological parameters when compared with the control. There was no significant increase in WBC in all the groups when compared with the control. White blood cell (leucocytes) are known to increase sharply when infection occurs, as one of the first line of defense of the body. The increase in PCV, Haemoglobin, RBC, Platelets, neutrophils counts following tiger nut, soya bean, groundnut, beniseed and crayfish supplements feeding for 4 weeks confirms the nutritional properties of these feeds.

\section{References}

1. (2016) Word health organization The WHO child growth standards.

2. Duggan C, Watkins JB, Walker WA (2008) Nutrition in pediatrics: Basic science, clinical application. BC Decker, Hamilton, pp. 127-141.

3. Pruss-Ustun A, Bos R, Gore F, Bartram J (2008) Safer water, better health - Costs, benefits and sustainability of interventions to protect and promote health. World Health Organization (WHO), Geneva, Switzerland, p. 53.

4. Bertinic C (2006) Report of the standing committee on Nutrition at its $33^{\text {rd }}$ session. World Health Organization, Geneva, Switzerland, p. 1-21.

5. Bhargava M, Aggarwal PSD, Kandpal, SD, Semwal J (2015) Magnitude of undernutrition in urban and rural school going children using World health organization reference standards. Ntl J Comm Med 6(4): 452-457.

6. Stillwaggon E (2008) Race, sex, and the neglected risks for women and girls in Sub-Saharan Africa. Feminist Eco 14(4): 67-86.

7. Schaible UE, Kaufmann SHE (2007) Malnutrition and infection: Complex mechanisms and global impacts. PLoS Med 4(5): e115. 
8. Amuna P, Zotor F, Chinyana YR (2000) The role of traditional cereals/ legumes/fruit based multi mix in weaning in developing countries. J Fd Sci Nutr 30: 116-122.

9. Fotso JC, Kuate-Defo B (2005) Measuring socioeconomic status in health research in developing countries: Should we be focusing on households, communities or both?. Soc Indic Res 72(2): 189-237.

10. Huffman SL, Martin LH (2001) First feedings: Optimal feeding of infants and toddlers. Nutr Res 14: 127-159.

11. Dean J, Edwards DG (1985) The availability to the rat of energy from various diets ingredients. Lab Ani 19(4): 305-310.

12. Bouafou KG M (2007) Study of the production of maggots from household refuse and the nutritional value of dried maggot meal (FAS) in growing rats. PhD Thesis Animal Physiology, University of Cocody, Abidjan, Ivory Coast, pp. 145.

13. Daniels JL, longnecker MP, Rowland AS, Golding J (2004) Fish intake during pregnancy and early cognitive development of offspring. Epidemiol 15(4): 394-402.

\section{ISSN: 2574-1241}

DOI: 10.26717/BJSTR.2019.21.003570

Umaru Hauwa Aduwamai. Biomed J Sci \& Tech Res

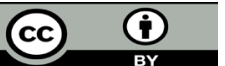

This work is licensed under Creative

Commons Attribution 4.0 License

Submission Link: https://biomedres.us/submit-manuscript.php
14. Sanchez-Zapata E, Fernandez-Lopez JA, Perez-Alvarez J (2012) Tiger Nut (Cyperus esculentus) commercialization: Health aspects, composition, properties, and food applications. Comprehen Rev Fd Sci Fd Safe 1(4): 366-377.

15. Adediran AM, Karim R, Oyeyinka SA Oyeyinka AT, Awonorin SO (2013) Physico-chemical properties and akara making potentials of preprocessed Jack beans Canavalia ensiformis) and Cowpea (Vigna unguiculata L. Walp) composite flour. Croatian J Fd Tech Biotech Nutri 8: 102.

16. Shafir T, Angulo-Barroso RS, (2009) Iron deficiency anemia in infancy and reach and grasp development. Infant Behav Dev 32: 366-375.

17. Maurice Edward Shils, Moshe Shike (2006) Modern nutrition in health and disease, $\left(10^{\text {th }} \mathrm{edn}\right)$. Lippincott Williams \& Wilkins, Baltimore, pp. 223- 247.

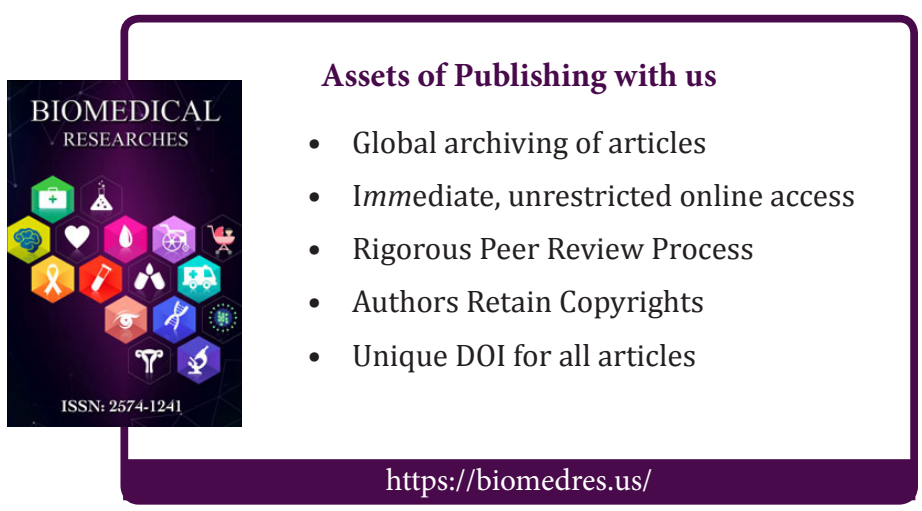

